\title{
Role of phosphodiesterase and protein kinase $G$ on nitric oxide-induced inhibition of prolactin release from the rat anterior pituitary
}

Miguel Omar Velardez, Andrea De Laurentiis, María del Carmen Díaz, Mercedes Lasaga, Daniel Pisera, Adriana Seilicovich and Beatriz Haydée Duvilanski

Centro de Investigaciones en Reproducción, Facultad de Medicina, Universidad de Buenos Aires, Argentina

(Correspondence should be addressed to B H Duvilanski, Centro de Investigaciones en Reproducción, Facultad de Medicina, Universidad de Buenos Aires, Paraguay 2155 Piso 10, 1121 Buenos Aires, Argentina; Email: duvilan@mail.retina.ar)

\begin{abstract}
Objective: In order to determine the mechanism by which nitric oxide (NO) inhibits prolactin release, we investigated the participation of cGMP-dependent cAMP-phosphodiesterases (PDEs) and protein kinase G (PKG) in this effect of NO.

Methods: Anterior pituitary glands of male rats were incubated with inhibitors of PDE and PKG with or without sodium nitroprusside (NP). Prolactin release, and cAMP and cGMP concentrations were determined by RIA.

Results and conclusions: The inhibitory effect of NP $(0.5 \mathrm{mmol} / \mathrm{l})$ on prolactin release and cAMP concentration was blocked by EHNA $\left(10^{-4} \mathrm{~mol} / \mathrm{l}\right)$ and HL-725 $\left(10^{-4} \mathrm{~mol} / \mathrm{l}\right)$, inhibitors of cGMPstimulated cAMP-PDE (PDE2). 8-Br-cGMP $\left(10^{-4}\right.$ and $\left.10^{-3} \mathrm{~mol} / \mathrm{l}\right)$, which mimics cGMP as a mediator of NP effects on prolactin release, also decreased cAMP concentration. Zaprinast $\left(10^{-4} \mathrm{~mol} / \mathrm{l}\right)$, a selective inhibitor of specific cGMP-PDE (PDE5), potentiated the NP effect on cAMP concentration. Rp-8-[(4-chlorophenyl)thio]-cGMP triethylamine (Rp-8-cGMP, $10^{-7}-10^{-6} \mathrm{~mol} / \mathrm{l}$ ), an inhibitor of PKG, reversed the effect of NP on prolactin release. The present study suggests that several mechanisms are involved in the inhibitory effect of NO on prolactin release. The activation of PDE2 by cGMP may mediate the inhibitory effect of NO on cAMP concentration and therefore on prolactin release. NO-activated PKG may also be participating in the inhibitory effect of NO on prolactin release.
\end{abstract}

European Journal of Endocrinology 143 279-284

\section{Introduction}

Nitric oxide (NO) is a diffusible gas with an important role in neuroendocrine functions $(1,2)$. In the anterior pituitary, NO is synthesized in gonadotrophs and follicle-stellate cells $(3,4)$, and exerts direct effects on pituitary hormone secretion (5-10). We recently demonstrated that NO, by a paracrine mechanism, inhibits prolactin release from rat anterior pituitaries in vitro (9). We also found that NO increases pituitary cGMP concentration and decreases cAMP concentration (11). In addition, NO induced a transient decrease in free intracellular calcium levels in anterior pituitary cells (12). cAMP and calcium are intracellular messengers that play important roles in the signal transduction mechanisms regulating prolactin secretion $(13,14)$.

cGMP regulates cellular responses through several different downstream mechanisms, including calcium influx $(15,16)$, protein phosphorylation by cGMPdependent protein kinase G (PKG) $(16,17)$ and stimulation or inhibition of phosphodiesterase (PDE) activity $(18,19)$. Several PDEs able to hydrolyze cAMP are regulated by cyclic nucleotides and hormones $(19,20)$. At least two cAMP-PDE families are controlled by cGMP (18): the cGMP-stimulated PDE (cGS-PDE or PDE2) increases cAMP hydrolysis, while the cGMPinhibited PDE (cGI-PDE or PDE3) decreases cAMP breakdown. Therefore, the intracellular concentration of cAMP can be regulated by modifying either its synthesis or its degradation. By controlling PDE activity, cGMP could modify cAMP concentration and consequently affect prolactin release.

PKG is the major intracellular receptor protein for cGMP $(15,16)$, and is involved in decreasing intracellular calcium levels $(16,17,21,22)$.

The expression and precise localization of PDE isoenzymes and PKG in a number of cell types and tissues have been determined recently (23). However, knowledge of the cellular distribution of these enzymes within the anterior pituitary is relatively limited. Only 
indirect demonstrations of their presence are reported by different authors $(24,25)$.

The relative contribution of $\mathrm{PDE}$ and $\mathrm{PKG}$ in the inhibitory effect of $\mathrm{NO}$ on prolactin release remains unknown. The aim of this study was to investigate some of the mechanisms by which NO decreases prolactin release. Since NO increased pituitary cGMP and decreased cAMP concentrations (11), we studied whether cGMP, through cGMP-stimulated PDE (PDE2), could mediate the NO effect on cAMP concentration and prolactin release. We also studied the participation of PKG in the effect of $\mathrm{NO}$ on prolactin release.

The results of this study show that NO through cGMP stimulates PDE2 activity, thus decreasing pituitary cAMP concentration and prolactin release. The stimulation of PKG activity by the NO/cGMP system is also involved in the effect of NO on prolactin release.

\section{Materials and methods}

\section{Rats}

Male Wistar rats (200-250g) were kept in controlled conditions of light ( $12 \mathrm{~h}$ light:12 h darkness cycle) and temperature $\left(21-24^{\circ} \mathrm{C}\right)$ with food and water freely available. Rats were kept according to the US National Institutes of Health (NIH) Guide for the Care and Use of Laboratory Animals. The animals were killed by decapitation and the anterior pituitary lobes removed, cut longitudinally into halves, and placed in KrebsRinger bicarbonate buffer, $\mathrm{pH} 7.4$ containing $10 \mathrm{mmol} / \mathrm{l}$ glucose, $25 \mathrm{mmol} / \mathrm{l}$ Hepes, $0.1 \mathrm{mmol} / \mathrm{l}$ bacitracin and $0.1 \%$ BSA (KRB buffer).

\section{Drugs}

HL-725, [2,3,6,7-tetrahydro-9,10-dimethoxy-3-methyl -2-[2,4,6-(trimethylphenyl)imino]-4H pirimido [6,1a]isoquinolin-4-one hydrochloride], and zaprinast, 1,4 -dihydro-5-[2-propoxyphenyl]-7H-1,2,3-triazolo[4,5d]pyrimidine-7-one, were purchased from ICN Pharm. Inc., CA, USA; EHNA, erythro-9-[2-hydroxy-3-nonyl]adenine, and Rp-8-cGMP, Rp-8-[(4-chlorophenyl)thio]cGMP triethylamine, from RBI, Natick, MA, USA. All other drugs were purchased from Sigma Chemical Co. (St Louis, MO, USA). Sodium nitroprusside (NP) was prepared $1 \mathrm{~min}$ before addition to the assay buffer.

\section{Incubation of anterior pituitary glands}

One hemipituitary per tube was preincubated for $60 \mathrm{~min}$ in $0.5 \mathrm{ml} \mathrm{KRB}$ buffer at $37^{\circ} \mathrm{C}$ to stabilize the tissue, in an atmosphere of $95 \% \quad \mathrm{O}_{2}: 5 \% \quad \mathrm{CO}_{2}$ with constant shaking at 60 cycles/min. Afterwards, the tissue was incubated in $0.45 \mathrm{ml}$ fresh KRB buffer containing the different inhibitors being studied (to give the inhibitors time to take effect before addition of NP). Fifteen minutes after starting the incubation,
$0.05 \mathrm{ml} 5 \mathrm{mmol} / \mathrm{l} \mathrm{NP}$ (to final concentration of $0.5 \mathrm{mmol} / \mathrm{l}$ ) or KRB buffer was added and incubations continued for 15 or $45 \mathrm{~min}$ more. Controls were incubated in medium alone or with the corresponding vehicles. At the end of the incubation period, the media were aspirated and samples stored at $-20{ }^{\circ} \mathrm{C}$ pending prolactin determination. Tissues were immediately frozen on dry ice and then processed for cyclic nucleotide and protein determination.

\section{Cyclic nucleotide determination}

Tissues were heated at $100{ }^{\circ} \mathrm{C}$ in $50 \mathrm{mmol} / \mathrm{l}$ sodium acetate buffer, $\mathrm{pH} 6.2$, for $5 \mathrm{~min}$. Tissues were sonicated for $30 \mathrm{~s}$ and centrifuged. Supernatants were stored at $-70{ }^{\circ} \mathrm{C}$ pending cyclic nucleotide measurement by specific RIAs, with rabbit cAMP antibody for RIA pool CV-27 provided by National Institute of Diabetes, Digestive and Kidney Diseases of the NIH (Bethesda, MD, USA). The intra- and interassay coefficients of variation were less than $9 \%$.

\section{Prolactin determination}

Prolactin was measured in the incubation medium by a double-antibody RIA, with kits provided by NIDDK, $\mathrm{NIH}$. The results were expressed in terms of rat prolactin (RP-3) standard. The intra- and interassay coefficients of variation were less than $9 \%$.

Protein concentration in tissue was determined by the Lowry method after sonication.

\section{Statistical analysis}

The results are expressed as means \pm s.E.M. and evaluated by one- or two-way ANOVA, followed by the Student-Newman-Keuls multiple comparison test for unequal replicates or Dunnett's test. The differences between groups were considered significant at $P<0.05$. Results were confirmed by at least three independent experiments.

\section{Results}

\section{Role of PDE2 in the NP effect on prolactin release and on CAMP and CGMP content}

In order to examine the effect of NP on prolactin release and cAMP concentration in the presence of PDE2 inhibitors, EHNA ( $\left.\mathrm{IC}_{50}: 10^{-6} \mathrm{~mol} / \mathrm{l}\right)$ and HL-725 $\left(\mathrm{IC}_{50}: 10^{-10} \mathrm{~mol} / \mathrm{l}\right.$ for the purified enzyme) $(18,26-28)$, we first tested the effect of these inhibitors alone on prolactin release. After $30 \mathrm{~min}$ incubation, neither EHNA nor HL-725 alone, at either concentration tested, affected prolactin release (control, $1.07 \pm$ $0.08 \mu \mathrm{g} / \mathrm{mg}$ protein; EHNA, $10^{-5} \mathrm{~mol} / \mathrm{l}, 1.07 \pm 0.05$, $10^{-4} \mathrm{~mol} / \mathrm{l}, 1.08 \pm 0.07, n=6$, Dunnett's test: control, 


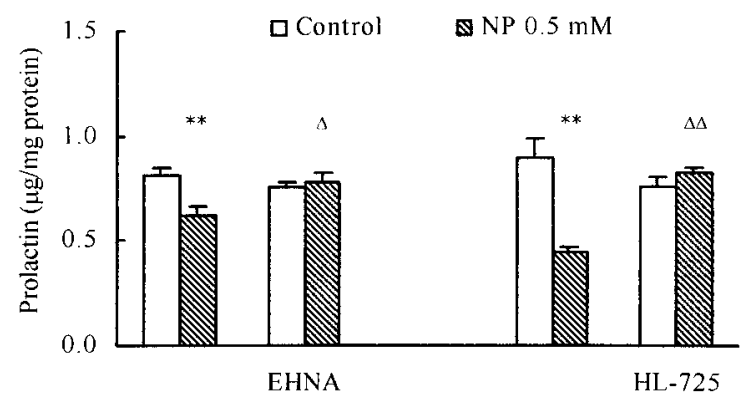

Figure 1 Effect of EHNA and HL-725, inhibitors of PDE2, on the inhibitory effect of NP on prolactin release. Anterior pituitary glands were incubated 30 and $60 \mathrm{~min}$ with $10^{-4} \mathrm{~mol} / \mathrm{l}$ EHNA or $10^{-4} \mathrm{~mol} / \mathrm{l} \mathrm{HL}-725$ and $0.5 \mathrm{mmol} / \mathrm{l} \mathrm{NP}$, as indicated in Materials and methods. The bars represent the means \pm S.E.M. $(n=6-9)$. Statistical significance was determined by two-way ANOVA followed by Student-Newman-Keuls post-hoc test. ${ }^{\star} P<0.05$, ${ }^{\star \star} P<0.01$ vs respective control without NP. ${ }^{\Delta} P<0.05,{ }^{\Delta \Delta} P<0.01$ vs respective control without inhibitor.

$1.01 \pm 0.06 \mu \mathrm{g} / \mathrm{mg}$ protein; HL-725, $10^{-6} \mathrm{~mol} / \mathrm{l}, 0.86$ $\pm 0.05,10^{-4} \mathrm{~mol} / \mathrm{l}, 0.90 \pm 0.04, n=6$, Dunnett's test). Similar results were observed when pituitaries were incubated for 60 min with EHNA and HL-725 (data not shown). Both EHNA and HL-725, at a concentration that did not modify per se prolactin release $\left(10^{-4} \mathrm{~mol} / \mathrm{l}\right)$, abolished the inhibitory effect of NP on this release (Fig. 1).

Both PDE2 inhibitors did not modify per se basal cAMP concentration. The inhibitory effect of NP on
cAMP concentration was not only blocked but even significantly increased in the presence of both EHNA and HL-725 (Fig. 2). We also evaluated the effect of $\mathrm{NP}$ on intracellular cGMP concentration in the presence of PDE2 inhibitors. Neither EHNA nor HL-725 $\left(10^{-4} \mathrm{~mol} / \mathrm{l}\right)$ had any effect per se on cGMP concentration, but significantly increased the effect of NP on this nucleotide (Fig. 2).

\section{Effect of exogenous and endogenous cGMP on intracellular cAMP concentration}

cGMP, which mediates the NO effect on prolactin release (11), also seems to mediate its effect on cAMP concentration. 8-Br-cGMP, a slowly hydrolyzable, membrane-permeable analogue of cGMP, significantly reduced cAMP concentration (control, $2.40 \pm$ $0.22 \mathrm{pmol} / \mathrm{mg}$ protein; $10^{-4} \mathrm{~mol} / \mathrm{l}$ 8-Br-cGMP, 1.25 $\pm 0.11,10^{-3} \mathrm{~mol} / \mathrm{l}$ 8-Br-cGMP, $1.42 \pm 0.23, n=5$, both $P<0.01$ vs control, ANOVA followed by Dunnett's test).

Zaprinast $\left(10^{-4} \mathrm{~mol} / \mathrm{l}\right)$, a selective inhibitor of cGMPPDE (scG-PDE, PDE5) ( $\left.\mathrm{IC}_{50}: 10^{-6} \mathrm{~mol} / \mathrm{l}\right)(18,29,30)$, did not affect cGMP or cAMP concentrations after $30 \mathrm{~min}$ incubation, but significantly increased the NP effect on cGMP and cAMP concentrations (Table 1). Zaprinast failed to modify the inhibitory effect of NP on prolactin release (Table 1), but after $60 \mathrm{~min}$ incubation, reduced basal prolactin release to levels similar to those reached by NP alone or with NP plus zaprinast (control, $1.54 \pm 0.09 \mu \mathrm{g} / \mathrm{mg}$ protein; $0.5 \mathrm{mmol} / \mathrm{l} \mathrm{NP}$,
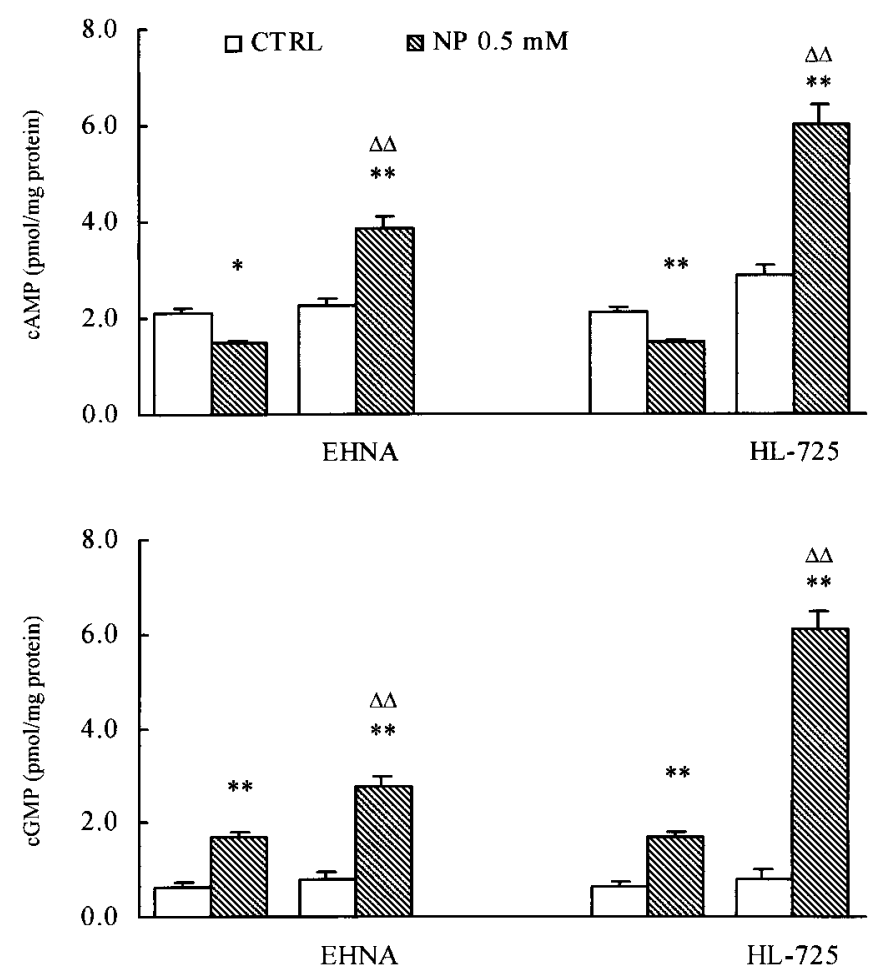

Figure 2 Effect of EHNA and HL-725 on changes induced by NP on cAMP and cGMP concentrations. Anterior pituitary glands were incubated $30 \mathrm{~min}$ with $10^{-4} \mathrm{~mol} / / \mathrm{EHNA}$ or $10^{-4} \mathrm{~mol} / \mathrm{l} \mathrm{HL}-725$ and $0.5 \mathrm{mmol} / \mathrm{l} \mathrm{NP}$, as indicated in Materials and methods. The bars represent the means \pm S.E.M. $(n=6-9)$. Statistical significance was determined by two-way ANOVA followed by Student-Newman-Keuls post-hoc test. ${ }^{\star} P<0.05,{ }^{\star} * P<0.01$ vs respective control without NP. ${ }^{\Delta \Delta} P<0.01$ vs respective control without inhibitor. 
Table 1 Effect of zaprinast, an inhibitor of PDE5, on changes induced by NP on prolactin release, cAMP and cGMP concentration. Anterior pituitary glands were incubated $30 \mathrm{~min}$ with $10^{-4} \mathrm{~mol} / / \mathrm{l}$ zaprinast and $0.5 \mathrm{mmol} / \mathrm{l} \mathrm{NP}$, as indicated in Materials and methods. Results are means \pm S.E.M. $(n=7-9)$.

\begin{tabular}{lccc}
\hline & $\begin{array}{c}\text { Prolactin } \\
(\mu \mathrm{g} / \mathrm{mg} \text { protein })\end{array}$ & $\begin{array}{c}\text { cAMP } \\
(\text { pmol/mg protein) }\end{array}$ & $\begin{array}{c}\text { cGMP } \\
(\text { pmol/mg protein) }\end{array}$ \\
\hline Control & $0.83 \pm 0.04$ & $2.38 \pm 0.08$ & $0.73 \pm 0.06$ \\
NP & $0.44 \pm 0.04^{\star *}$ & $1.94 \pm 0.08^{*}$ & $1.81 \pm 0.20$ \\
Zaprinast & $0.76 \pm 0.06$ & $2.52 \pm 0.08$ & $1.18 \pm 0.13$ \\
NP + zaprinast & $0.52 \pm 0.04^{\star *}$ & $1.03 \pm 0.22^{\star *, \Delta \Delta}$ & $2.74 \pm 0.32^{\star *, \Delta \Delta}$
\end{tabular}

${ }^{\star} P<0.05,{ }^{* *} P<0.01$ vs respective control without NP; ${ }^{\Delta \Delta} P<0.01$ vs respective control without zaprinast. Determined by two-way ANOVA followed by Student-Newman-Keuls test.

$1.15 \pm 0.10^{* *} ; 10^{-4} \mathrm{~mol} / \mathrm{l}$ zaprinast, $1.01 \pm 0.02^{\Delta \Delta}$; $\mathrm{NP}+$ zaprinast, $1.10 \pm 0.04^{* *}, n=5$ or $6,{ }^{* *} P<0.01$ vs control without NP, ${ }^{\Delta \Delta} P<0.01$ vs respective control without zaprinast, ANOVA followed by StudentNewman-Keuls test).

\section{Role of PKG in the NP effect on prolactin release}

Since NO through cGMP can stimulate PKG, we next considered the role of these enzymes in the effect of NP on prolactin release. For this purpose, we used Rp-8cGMP, an inhibitor of PKG $(31,32)$. Anterior pituitary glands were incubated with increasing concentrations of Rp-8-cGMP $\left(10^{-8}-10^{-6} \mathrm{~mol} / \mathrm{l}\right)$ for 30 and $60 \mathrm{~min}$. At these concentrations, PKG inhibitor did not modify basal prolactin release per se at either incubation time (Table 2). However, when anterior pituitaries were incubated with NP, the PKG inhibitor reversed the inhibitory effect of NP on prolactin release (Fig. 3).

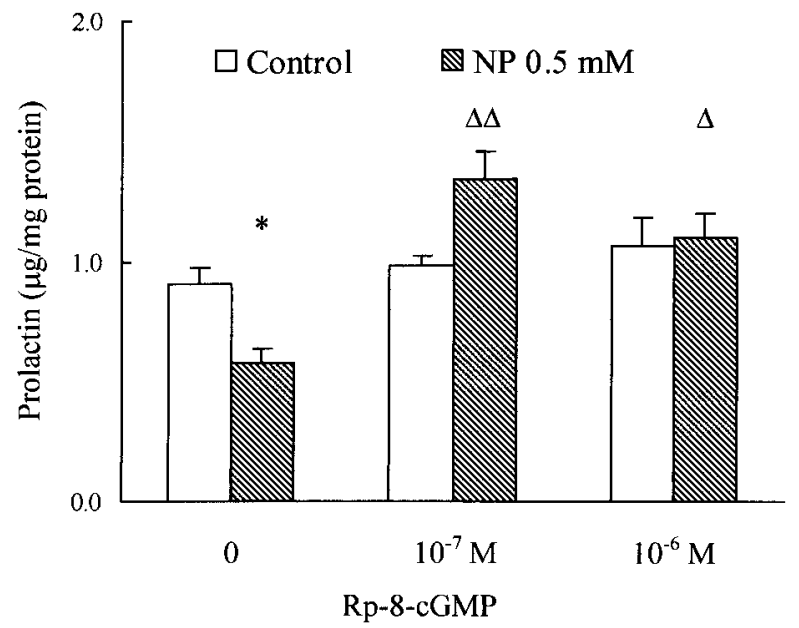

Figure 3 Effect of Rp-8-cGMP, an inhibitor of PKG, on the inhibitory effect of NP on prolactin release. Anterior pituitary glands were incubated $30 \mathrm{~min}$ with Rp-8-cGMP and $0.5 \mathrm{mmol} / \mathrm{l} \mathrm{NP}$, as indicated in Materials and methods. The bars represent the means \pm S.E.M. ( $n=7-9)$. Statistical significance was determined by two-way ANOVA followed by Student-Newman-Keuls post-hoc test. ${ }^{\star} P<0.05$, vs respective control without NP. ${ }^{\Delta} P<0.05,{ }^{\Delta \Delta} P<0.01$ vs respective control without inhibitor.

\section{Discussion}

The aim of this study was to characterize some of the intracellular mechanisms by which NO inhibits prolactin release. Our present data show that at least two mechanisms, the activation of the PDE2 and the PKG, may be involved in the inhibitory effect of the NO/cGMP system on prolactin release.

cGMP regulates several of the PDEs that hydrolyze cAMP (18), such as PDE2 and PDE3. Both PDEs hydrolyze cAMP and cGMP. However, PDE2 contains a non-catalytic binding site for cGMP that, in the presence of cGMP, increases its affinity for cAMP, with greater hydrolyzing capacity for cAMP than for cGMP $(18,19)$. Although the cellular distribution of PDE isoenzymes within the anterior pituitary remains unknown, it has been observed that PDE2 prevails in tissues where the two cyclic nucleotides have opposite effects $(18,19)$. Our data show that NP and 8-Br-cGMP, which mimics cGMP, reduce pituitary cAMP concentration. Since the effect of NP on cAMP content is potentiated by inhibiting cGMP breakdown, we can assume that cGMP may be activating PDE2. Supporting our hypothesis, when PDE2 was inhibited by EHNA or HL-725, NP not only failed to decrease cAMP concentration but even increased it. This increase in cAMP caused by cGMP could result from two simultaneous effects, one being the inability of cGMP to stimulate PDE2 in the presence of EHNA and HL-725, and the other being exerted by cGMP on PDE3. Also, since PDE2 hydrolyzes cGMP as well, NP induced a higher cGMP concentration in the presence of the PDE2 inhibitors.

NO inhibits prolactin by a paracrine mechanism (9) and increases intrapituitary cGMP content by stimulating guanylyl cyclase activity. cGMP mediates NO effects on prolactin release (11). Although evidence for cGMP production in lactotrophs has not been obtained to date (33), our results indicate that this cyclic nucleotide participates in the regulation of prolactin release.

HL-725 is a potent inhibitor of purified PDE2 in vitro $(27,28)$, though it is not totally selective $(34,35)$. Because NP produced a higher increase in cAMP with HL-725 than with EHNA, it is possible that HL-725 
Table 2 Effect of increasing concentrations of Rp-8-cGMP, an inhibitor of PKG, on prolactin release. Anterior pituitary glands were incubated with Rp-8-cGMP for 30 or $60 \mathrm{~min}$. Results are means \pm S.E.M. $(n=6)$.

\begin{tabular}{|c|c|c|}
\hline \multirow[b]{2}{*}{ Rp-8-cGMP (mol/l) } & \multicolumn{2}{|c|}{ Prolactin ( $\mu \mathrm{g} / \mathrm{mg}$ protein) } \\
\hline & $30 \mathrm{~min}$ & $60 \mathrm{~min}$ \\
\hline Control & $0.83 \pm 0.08$ & $1.34 \pm 0.09$ \\
\hline $10^{-8}$ & $1.09 \pm 0.10$ & $1.40 \pm 0.19$ \\
\hline $10^{-7}$ & $1.12 \pm 0.11$ & $1.54 \pm 0.14$ \\
\hline $10^{-6}$ & $1.09 \pm 0.09$ & $1.24 \pm 0.10$ \\
\hline
\end{tabular}

No statistical significance, determined by one-way ANOVA followed by Dunnett's test.

could also be inhibiting PDE3. In spite of the high concentrations of PDE inhibitors used in our experiments, they affect neither basal prolactin release nor cAMP and cGMP content per se, suggesting that the activity of the enzymes is low under non-stimulated conditions, so that the effect of the inhibitors can be detected only when the enzymes are stimulated.

Zaprinast, a specific inhibitor of $\operatorname{PDE} 5(29,30)$, did not by itself affect either cGMP or cAMP concentrations, but enhanced the response to NP of these cyclic nucleotides. The increase in cGMP concentration induced by NP plus zaprinast may induce strong activation of PDE2 (20), thus potentiating the inhibitory effect of NP on cAMP content. Zaprinast alone and at the concentration tested, did not modify prolactin release after a short incubation period, but inhibited its release when pituitaries were incubated for a long period. Because NO is tonically released by anterior pituitary cells (9), basal synthesis of cGMP may be occurring constantly. The inhibition of prolactin release induced by zaprinast in long-term incubation could be the consequence of a continuous and persistent effect of cGMP on prolactin release. Although zaprinast potentiated the effect of NP on concentration of cyclic nucleotides, it did not affect the inhibitory effect of NP on prolactin release, suggesting that NO could modify cyclic nucleotides in several cell types of the anterior pituitary. Also, a high concentration of cGMP may stimulate PKA pathways (36) and consequently counteract the NP effect on prolactin release.

It has been demonstrated that dopamine, the most potent prolactin release inhibitor, can decrease prolactin release even when cAMP concentrations are high, because dopamine inhibits prolactin release by other mechanisms besides the inhibition of adenylate cyclase $(13,37)$. In our experimental conditions, when PDE2 activity was inhibited and cAMP concentration increased, NP was unable to inhibit prolactin release but prevented the increase of prolactin release expected to be induced by the increase of cAMP. Therefore, it is possible that, since the concentration of both cyclic nucleotides was higher, the stimulatory effects of
cAMP on prolactin release could be masked by opposite effects of cGMP through other mechanisms influenced by NO/cGMP. Supporting this hypothesis, the inhibition of $\mathrm{PKG}$, the main protein receptor of cGMP, also reversed the inhibitory effect of NP on prolactin release. These findings suggest that PKG may be involved in the inhibitory effect of NO on prolactin release. cGMP stimulates PKG activity, which can in turn decrease intracellular $\mathrm{Ca}^{2+}$ levels (15-17). Transmembrane $\mathrm{Ca}^{2+}$ influx seems to be an important mechanism regulated by NO $(12,17,38)$. Also, we cannot discard direct effects of NO on different enzymes, such as on adenylate cyclase $(39,40)$ or lipooxygenase $(41)$, as has been demonstrated in several tissues. In fact, these enzymes in the pituitary are involved in the regulation of prolactin release (13).

In summary, the present study suggests that different mechanisms are involved in the inhibitory effect of NO on prolactin release. The increase of cGMP induced by NO may activate both PDE2 and PKG enzymes. Through these mechanisms the NO/cGMP system decreases anterior pituitary cAMP content and may affect events associated with calcium mobilization. Thus, NO may control prolactin release through multiple and integrated actions.

\section{Acknowledgements}

The authors wish to thank NIH for providing prolactin and cAMP kits. They also thank Dr Omar Pignataro from IByME, Argentina, for supplying the labeled cyclic nucleotides. This project was supported by grants from the Consejo Nacional de Investigaciones Científicas y Técnicas (CONICET) and the Universidad de Buenos Aires, Argentina.

\section{References}

1 Murad F. Regulation of cytosolic guanylyl cyclase by nitric oxide: the NO-cyclic GMP signal transduction system. Advances in Pharmacology 199426 19-33.

2 Brann DW, Bhat GK, Lamar CA \& Mahesh VB. Gaseous transmitters and neuroendocrine regulation. Neuroendocrinology 199765 385-395.

3 Ceccatelli S, Hulting AL, Zhang X, Gustafsson L, Villar M \& Hökfelt T. Nitric oxide synthase in rat anterior pituitary gland and the role of nitric oxide in regulation of luteinizing hormone secretion. PNAS $19939011292-11296$.

4 Lloyd RV, Jin L, Qian S \& Scheithauer BW. Nitric oxide synthase in the human pituitary gland. American Journal of Pathology 1995 146 86-94.

5 Brunetti L, Preziosi P \& Ragazzoni E. Involvement of nitric oxide in basal and interleukin-1-beta-induced CRF and ACTH release in vitro. Life Sciences 199353 PL219-PL222.

6 Hashimoto K, Nishioka T, Tojo C \& Takao T. Nitric oxide plays no role in ACTH release induced by interleukin-1-beta, corticotropin-releasing hormone, arginine vasopressin and phorbol myristate acetate in rat pituitary cell cultures. Endocrinological Journal $199542435-439$.

7 Kato M. Involvement of nitric oxide in growth hormone (GH)releasing hormone-induced $\mathrm{GH}$ secretion in rat pituitary cells. Endocrinology 1992131 2133-2138. 
8 Tena-Sempere M, Pinilla L, Gonzalez D \& Aguilar E. Involvement of endogenous nitric oxide in the control of pituitary responsiveness to different elicitors of growth hormone release in prepuberal rats. Neuroendocrinology 199664 146-152.

9 Duvilanski BH, Zambruno C, Seilicovich A, Pisera D, Lasaga M, Diaz MC, Belova N, Rettori V \& McCann SM. Role of nitric oxide in control of prolactin release by adenohypophysis. PNAS 1995 92 170-174.

10 Brunetti L, Ragazzoni E, Preziosi P \& Vacca M. A possible role for nitric oxide but not for prostaglandin E2 in basal and interleukin-1-beta-induced PRL release in vitro. Life Sciences 1995 56 PL277-PL283.

11 Duvilanski BH, Zambruno C, Lasaga M, Pisera D \& Seilicovich A. Role of nitric oxide/cyclic GMP pathway in the inhibitory effect of GABA and dopamine on prolactin release. Journal of Neuroendocrinology 19968 909-913.

12 Duvilanski BH, Velardez MO, Gonzalez-Iglesias A, Theas S, Seilicovich A \& Becu-Villalobos D. Nitric oxide donors modify free intracellular calcium levels in rat anterior pituitary cells. Molecular and Cellular Endocrinology 1998146 19-26.

13 Martinez de la Escalera G \& Weiner R. Dissociation of dopamine from its receptor as a signal in the pleiotropic hypothalamic regulation of prolactin secretion. Endocrine Reviews 199213 241-255.

14 Burgoyne RD \& Morgan A. Regulated exocytosis. Biochemical Journal 1993293 305-316.

15 Lincoln TM \& Cornwell TL. Intracellular cyclic GMP receptor proteins. FASEB Journal $19937328-338$.

16 Wang X \& Robinson PJ. Cyclic GMP-dependent protein kinase and cellular signalling in the nervous system. Journal of Neurochemistry $199718443-456$.

17 Cornwell TL \& Lincoln TM. Regulation of intracellular $\mathrm{Ca}^{++}$levels in cultured vascular smooth muscle cells. Reduction of $\mathrm{Ca}^{++}$by atriopeptin and 8-bromo-cyclic GMP is mediated by bromo-cyclic GMP-dependent protein kinase. Journal of Biological Chemistry $19892641146-1155$.

18 Beavo JA. Cyclic nucleotide phosphodiesterases: functional implications of multiple isoforms. Physiological Reviews 199575 725-748.

19 Conti M, Nemoz G, Sette C \& Vicini E. Recent progress in understanding the hormonal regulation of phosphodiesterases. Endocrine Reviews 199516 370-389.

20 Sonnenburg WK \& Beavo J. Cyclic GMP and regulation of cyclic nucleotide hydrolases. Advances in Pharmacology 199426 $87-114$.

21 Oliva AM \& García A. Cyclic GMP inhibition of stimulated phosphoinositide hydrolysis in neural cultures. NeuroReport 1995 6 565-568.

22 Dufour JF, Turner TJ \& Arias IM. Nitric oxide blocks bili canalicular contraction by inhibiting inositol triphosphatedependent calcium mobilization. Gastroenterology 1995108 841-849.

23 Dousa TP. Cyclic- $3^{\prime}, 5^{\prime}$-nucleotide phosphodiesterase isozymes in cell biology and pathophysiology of kidney. Kidney International $19995529-62$.

24 Sakakibara H, Conti M \& Weiner R. Role of phosphodiesterases in the regulation of gonadotropin-releasing hormone secretion in GT1 cells. Neuroendocrinology 199868 365-373.

25 Cataldi M, Secondo A, D'Alessio A, Sarnacchiaro F, Colao AM, Amoroso S, Di Renzo GF \& Annunziato L. Involvement of phosphodiesterase-cGMP-PKG pathway in intracellular $\mathrm{Ca}^{2+}$ oscillations in pituitary $\mathrm{GH}_{3}$ cells. Biochimica et Biophysica Acta $19991449186-193$.

26 Podzuweit T, Nennstiel P \& Muller A. Isozyme selective inhibition of cGMP-stimulated cyclic nucleotide phosphodiesterases by erythro-9-(2-hydroxy-nonyl) adenine. Cell Signalling 19957 $733-738$.
27 Whalin ME, Strada SJ \& Thompson WJ. Purification and partial characterization of membrane-associated type II (cGMP-activatable) cyclic nucleotide phosphodiesterase from rabbit brain. Biochimica et Biophysica Acta 1998972 79-94.

28 Whalin ME, Scammell JG, Strada SJ \& Thompson WJ. Phosphodiesterase II, the cGMP-activatable cyclic nucleotide phosphodiesterase, regulates cyclic AMP metabolism in PC12 cells. Molecular Pharmacology 199139 711-717.

29 Wilkins MR, Settle SL \& Needleman P. Augmentation of the natriuretic activity of exogenous and endogenous atriopeptin in rats by inhibition of guanosine $3^{\prime}, 5^{\prime}$-cyclic monophosphate degradation. Journal of Clinical Investigation 199085 1274-1279.

30 Dundore RL, Pratt PF, Hallenbeck WD, Wassey ML, Silver PJ \& Buchholz RA. Sodium nitroprusside potentiates the depressor response to the phosphodiesterase inhibitor zaprinast in rats. European Journal of Pharmacology 1990185 91-97.

31 Butt E, Eigenthaler M \& Genieser H-G. (Rp)-8-pCPT-cGMPS, a novel cGMP-dependent protein kinase inhibitor. European Journal of Pharmacology, Molecular Pharmacology Section 1994 $269265-268$.

32 Pineda J, Kogan JH \& Aghajanian GK. Nitric oxide and carbon monoxide activate locus coeruleus neurons through a cGMPdependent protein kinase: involvement of a non selective cationic channel. Journal of Neuroscience 199616 1389-1399.

33 Yamada K, Xu ZQ, Zhang X, Gustafsson L, Hulting AL, Vente J, Steinbusch HWM \& Hökfelt T. Nitric oxide synthase and cGMP in the anterior pituitary gland: effect of a GnRH antagonist and nitric oxide donors. Neuroendocrinology 199765 147-156.

34 Rupert D \& Weithmann KU. HL-725, an extremely potent inhibitor of platelet phosphodiesterase and induced platelet aggregation in vitro. Life Sciences 198231 2037-2043.

35 Konkle BA, Kollros PR \& Kelly MD. Heparin-binding growth factor-1 modulation of plasminogen activator inhibitor-1 expression. Interaction with cAMP and protein kinase C-mediated pathways. Journal of Biological Chemistry 1990265 21867-21873.

36 Lincoln TM, Komalavilas P, Boerth N, MacMillan-Crow LA \& Cornwell TL. cGMP signaling through cAMP- and cGMPdependent protein kinases. Advances in Pharmacology 199534 305-322.

37 Delbeke D, Schammell JG, Martinez-Campos A \& Dannies P. Dopamine inhibits prolactin release when cyclic adenosine $3^{\prime}, 5^{\prime}$ monophosphate levels are elevated. Endocrinology 1986118 1271-1277.

38 Rivet-Bastide M, Vandecasteele G, Hatem S, Verde I, Benardeau A, Mercadier JJ \& Fischmeister R. cGMP-stimulated cyclic nucleotide phosphodiesterase regulates the basal calcium current in human atrial myocytes. Journal of Clinical Investigation 199799 2710-2718.

39 Maurice DH \& Haslam RJ. Molecular bases of the synergistic inhibition of platelet function of nitrovasodilators and activators of adenylate cyclase: inhibition of cyclic AMP breakdown by cyclic GMP. Molecular Pharmacology 199037 671-681.

40 Stefano GB, Salzet M, Magazine HI \& Bilfinger TV. Antagonism of LPS and IFN-gamma induction of iNOS in human saphenous vein endothelium by morphine and anadamide by nitric oxide inhibition of adenylate cyclase. Journal of Cardiovascular Pharmacology $199831813-820$.

41 Maccarrone M, Corasaniti MT, Guerrieri P, Nistico G \& Agro AF. Nitric oxide-donor compounds inhibit lipooxygenase activity. Biochemical and Biophysical Research Communications 1996219 128-133.

Received 29 December 1999

Accepted 20 April 2000 